\title{
Glycol mud improves drilling performance in Chinese fields
}

\author{
Chang Hong Gao ${ }^{1}$ (1)
}

Received: 20 March 2020 / Accepted: 5 May 2020 / Published online: 12 May 2020

(c) The Author(s) 2020

\begin{abstract}
Growing demand for oil and gas has driven drilling activities to deep formations and complex well structures. Drilling fluid must be able to maintain wellbore integrity and thermal stability over extended drilling time. Besides, drilling fluid should produce high rate of penetration (ROP) and low damage to formation rock. Glycol mud satisfies these criteria thanks to its unique cloud point phenomenon. When temperature exceeds cloud point temperature, glycol starts precipitate from mud by forming micelles, coats the rock surface, and plugs the small fractures in rocks. As a result, the flow of mud into rocks is restricted and wellbore stability is improved. This paper surveys more than 40 wells that were drilled with glycol mud. Field cases reported good wellbore integrity, thermal stability, high ROP, and low formation damage. Glycol mud is an excellent choice for battling well instability and high temperatures.
\end{abstract}

Keywords Drilling fluid $\cdot$ Glycol $\cdot$ Wellbore stability $\cdot$ Shale $\cdot$ Survey

\section{Introduction}

Despite many years of research and practices, wellbore instability remains a major challenge for drilling oil and gas wells (Gao 2019). Wellbore instability may result in well pack-off, stuck pipe, lost borehole, and costly sidetracking. Wellbore stability is controlled by the complex mechanical and chemical factors such as earth stresses, rock strength, pore pressure, mud pressure, and mud chemistry (Bol et al. 1994). The problem of wellbore instability due to reactive shale is well known in the drilling industry. It is estimated that $75 \%$ of the formations consist of shale rocks. Shales are mainly composed of mud, silts, and clays. Clay minerals are flaky, mica-type crystalline in nature. Among the clay minerals, smectite has a high cation exchange capacity (CEC); therefore, it is prone to swelling and dispersion when in contact with water (Li et al. 2012). Illite, chlorite, and kaolinite have low CEC and low tendency to swell. However, another type of illite is produced by the transformation of smectite under high pressure and high temperature. This mixed layer illite has more tendency to swell than its original form.

Oil-based mud (OBM) is widely used for drilling through troublesome shale formations (Gao 2017). OBM contains

Chang Hong Gao

USAUAE@163.COM

1 Yanshan University, Qinhuangdao, China small fraction of water, therefore reducing the swelling and dispersion of shale due to water invasion. However, the use of OBM is often restricted due to its environmental impacts (particularly in offshore drilling), high costs, and safety issue (Amani et al. 2012). Therefore, the design and development of water-based mud (WBM) with OBM performance is currently seen as an area of great interest in the oil industry.

One of the high-performance WBMs is glycol mud. A glycol is soluble at low temperatures, but starts to form micelles (molecular agglomerates) as the temperature is raised, thus becoming cloudy. The temperature at which this phenomenon occurs is named the cloud point temperature (CPT). Glycols, usually polyethylene glycol (PEG), are often used as shale inhibitors. The purported mechanism is that the glycol clouds out at higher downhole temperatures, coating the surface of clays and preventing shale hydration (Wang et al. 2009). Research also revealed that glycol effectively improved the thermal stability of certain polymers, thus reducing fluid loss and enhancing wellbore stability under high temperatures (Hu et al. 2003).

The cloud point temperature is influenced by glycol concentration. When glycol concentration increases, CPT first declines and then recovers, as shown in Fig. 1. Accordingly, glycol concentration of 2-5\% is recommended in field implementation to take advantage of low CPT (Wang et al. 2009). Moreover, inorganic salts depress the CPT of glycol. For instance, when $\mathrm{NaCl}$ concentration increases to $10 \%$, 


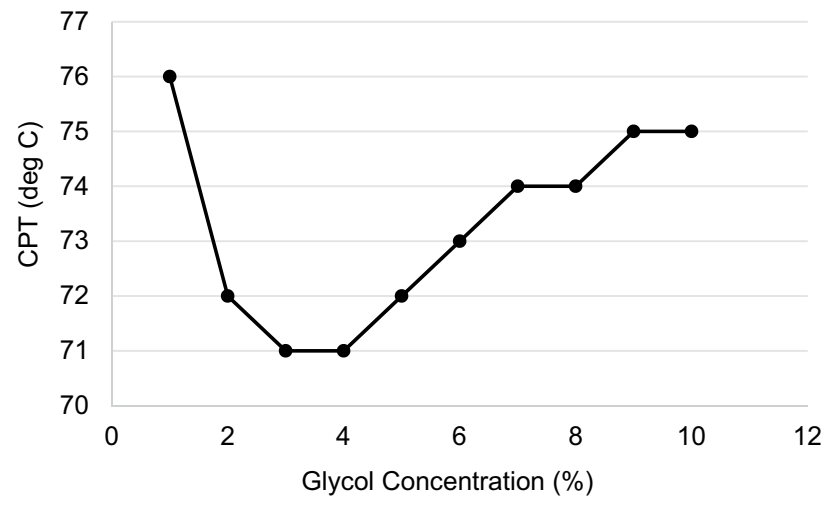

Fig. 1 Effect of glycol concentration on CPT

Table 1 Drilling program for Boshen-8

\begin{tabular}{lcl}
\hline Casing program & $\begin{array}{l}\text { Casing setting depth } \\
(\mathrm{m})\end{array}$ & Bit size $(\mathrm{mm})$ \\
\hline Conductor casing & 357 & 444.5 \\
Surface casing & 3228 & 311.2 \\
Intermediate casing & 4860 & 177.8 \\
Production casing & 5307 & 165.1 \\
\hline
\end{tabular}

effectively reduce filtrate loss and inhibit shale swelling. Moreover, relatively low pore pressure zone lays above the shale zone. High density mud may fracture the upper zone and result in lost circulation. As a result, mud density must be controlled carefully not to exceed formation fracturing pressure (Gao 2018).

Base mud contained clay and mud additives for HTHP applications, as shown in Table 2. The polymer and resin additives were applied to reduce filtrate loss, improve shale stability, and provide lubrication for drill bit and drill string. The base mud samples were aged at high temperatures for $16 \mathrm{~h}$, and the mud properties were tested and are presented in Table 3. Test data revealed the base mud maintained high viscosity and moderate filtrate loss. In other words, the base mud was able to function properly under high temperatures.

Glycol and salt, such as $\mathrm{NaCl}$ and $\mathrm{KCl}$, are often added to mud to inhibit shale swelling. Their effects on mud properties are presented in Table 4. After $\mathrm{NaCl}$ was added, both mud gel strength and filtrate loss increased. On the other hand, filtrate loss declined after glycol is applied, which revealed glycol reduced shale swelling by effectively reducing filtrate loss. With the selected mud system, the filtrate loss remained less than $12 \mathrm{ml}$ during drilling, which lead to good wellbore integrity. The mud achieved good stability

Table 2 Base mud formula

\begin{tabular}{lcl}
\hline Material & Concentration & Function \\
\hline Clay & $3 \%$ & To provide initial viscosity \\
PA-1 (modified polyamide) & $2 \%$ & To reduce filtrate loss at HPHT \\
SPNH (lignite resin) & $1 \%$ & To inhibit shale and provide lubrication \\
SPC (modified resin) & $3 \%$ & To reduce filtrate loss at HPHT \\
\hline
\end{tabular}

CPT drops from 75 to $65{ }^{\circ} \mathrm{C}$. When $\mathrm{CaCl}_{2}$ concentration reaches $10 \%$, CPT is depressed to $60{ }^{\circ} \mathrm{C}$.

\section{Field cases}

In recent years, glycol mud gained popular field implementations, especially in China. Some typical field cases are surveyed in this section. These valuable field experiences can improve our understanding of glycol mud and serve as the guidance for future implementations of glycol mud.

\section{Bohai Bay, China}

Well Boshen- 8 was an exploration well drilled by Sinopec in Bohai Bay. The well was completed at 5,307 m, where the bottom-hole temperature reached $200{ }^{\circ} \mathrm{C}$ (Niu 2010). The drilling program is given in Table 1 . Brittle shale was encountered below $3200 \mathrm{~m}$ TVD, which resulted in high risk of shale sloughing. Therefore, the mud system must
Table 3 Effect of temperature on mud properties

\begin{tabular}{llllll}
\hline Test sample & Aging conditions & $\begin{array}{l}\text { PV } \\
(\mathrm{cp})\end{array}$ & $\begin{array}{l}\text { YP } \\
(\mathrm{Pa})\end{array}$ & $\begin{array}{l}\text { Gel strength } \\
10 \mathrm{~min}(\mathrm{~Pa})\end{array}$ & $\begin{array}{l}\text { Filtrate } \\
(\mathrm{ml})\end{array}$ \\
\hline Base mud & No aging & 30 & 3 & 4 & 5 \\
Base mud & $180^{\circ} \mathrm{C} / 16 \mathrm{~h}$ & 20 & 2 & 1 & 4 \\
Base mud & $220^{\circ} \mathrm{C} / 16 \mathrm{~h}$ & 32 & 6 & 5 & 4 \\
Base mud & $250{ }^{\circ} \mathrm{C} / 16 \mathrm{~h}$ & 25 & 11 & 5 & 7 \\
\hline
\end{tabular}

and lubricity at $200{ }^{\circ} \mathrm{C}$. As a result, the drilling and tripping operations were smooth without incidents.

Three wells were drilled at Yuedong block of Bohai Bay from an artificial island (Liao et al. 2014). It was a challenge to maintain wellbore stability because unconsolidated mudstone was encountered at several depths. The drilling mud contained 3\% PEG, $4 \% \mathrm{KCl}$, and necessary additives to control filtrate loss under $4 \mathrm{ml}$. While drilling, mud funnel viscosity was around 56-62 s, and 
Table 4 Effect of salt and glycol on mud properties

\begin{tabular}{llllll}
\hline Test sample & Aging condition & $\begin{array}{l}\text { PV } \\
(\mathrm{cp})\end{array}$ & $\begin{array}{l}\text { YP } \\
(\mathrm{Pa})\end{array}$ & $\begin{array}{l}\text { Gel strength } \\
(\mathrm{Pa})\end{array}$ & $\begin{array}{l}\text { Filtrate } \\
\text { loss (ml) }\end{array}$ \\
\hline Base mud & $250^{\circ} \mathrm{C} / 16 \mathrm{~h}$ & 25 & 11 & 5 & 7 \\
Salt mud (base mud $+5 \% \mathrm{NaCl})$ & No aging & 23 & 10 & 35 & 9 \\
Salt mud (base mud $+5 \% \mathrm{NaCl})$ & $250^{\circ} \mathrm{C} / 16 \mathrm{~h}$ & 44 & 27 & 50 & 7 \\
Glycol mud (base mud $+5 \%$ glycol) & No aging & 12 & 2 & 25 & 2 \\
Glycol mud (base mud $+5 \%$ glycol) & $250^{\circ} \mathrm{C} / 16 \mathrm{~h}$ & 13 & 2 & 23 & 3 \\
\hline
\end{tabular}

Table 5 Comparison of glycol mud and oil-based mud

\begin{tabular}{|c|c|c|c|c|c|}
\hline Well No. & Mud Type & Interval & $\begin{array}{l}\text { Inclina- } \\
\text { tion angle } \\
\text { (deg.) }\end{array}$ & $\begin{array}{l}\text { ROP } \\
(\mathrm{m} / \mathrm{h})\end{array}$ & $\begin{array}{l}\text { Mud } \\
\text { specific } \\
\text { gravity }\end{array}$ \\
\hline A7 & $\begin{array}{c}\text { Glycol } \\
\text { mud }\end{array}$ & $\begin{array}{r}3636- \\
4206\end{array}$ & 20.25 & 18.00 & 1.46 \\
\hline A11 & $\begin{array}{c}\text { Glycol } \\
\text { mud }\end{array}$ & $\begin{array}{r}3483- \\
4106\end{array}$ & 24.87 & 16.93 & 1.45 \\
\hline A 23 & $\begin{array}{c}\text { Glycol } \\
\text { mud }\end{array}$ & $\begin{array}{r}3728- \\
4181\end{array}$ & 46.00 & 13.32 & 1.15 \\
\hline A17 & $\begin{array}{c}\text { Glycol } \\
\text { mud }\end{array}$ & $\begin{array}{r}3847- \\
4860\end{array}$ & 36.91 & 10.58 & 1.54 \\
\hline A 15 & $\begin{array}{c}\text { Glycol } \\
\text { mud }\end{array}$ & $\begin{array}{r}4038- \\
5060\end{array}$ & 47.80 & 11.78 & 1.52 \\
\hline A1 & OBM & $\begin{array}{r}3654- \\
5010\end{array}$ & 36.32 & 10.47 & 1.53 \\
\hline $\mathrm{A} 2$ & OBM & $\begin{array}{r}3442- \\
4398\end{array}$ & 21.00 & 9.91 & 1.54 \\
\hline A5 & OBM & $\begin{array}{r}3077- \\
4073\end{array}$ & 0 & 9.51 & 1.61 \\
\hline A18 & OBM & $\begin{array}{r}3277- \\
3730\end{array}$ & 12.22 & 4.00 & 1.52 \\
\hline
\end{tabular}

mud YP was around $11 \mathrm{~Pa}$. Solid control equipment was operated at high capacity. The wellbore drilled with PEG mud measured lower washout (15-18\%) than nearby wells drilled with other muds (23-25\%). It proved that PEG was effective at enhancing wellbore stability.

Seven directional wells were drilled with glycol mud at BZ251 block in Bohai Bay (Liu and Guo 2014). The reservoir featured low porosity, low permeability, and abnormal pore pressure. Drilling was faced with high risks of formation damage and lost circulation. The mud was formulated with sea water, $3 \%$ glycol, $5 \%$ potassium formate, and other chemicals. While drilling, mud funnel viscosity was 40-45 s, mud PV was 14-24 cP, mud YP was 9-15 Pa, API filtrate loss was below $3 \mathrm{ml}$, and HTHP filtrate loss was less than $10 \mathrm{ml}$. Drilling was successful without accidents. Among the seven wells, five wells were flowing naturally upon completion, which indicated that glycol mud effectively protected formation permeability. Glycol mud achieved higher ROP than nearby wells drilled with OBM, as shown in Table 5.
Table 6 Drilling program for Nanpu-54

\begin{tabular}{lcl}
\hline Casing program & $\begin{array}{l}\text { Casing setting depth } \\
(\mathrm{m})\end{array}$ & Bit size $(\mathrm{mm})$ \\
\hline Conductor casing & 300 & 660.4 \\
Surface casing & 2340 & 444.5 \\
Intermediate casing & 4421 & 311.2 \\
Intermediate casing & 5359 & 215.9 \\
Production casing & 5500 & 152.4 \\
\hline
\end{tabular}

\section{Jidong field, China}

Jidong field occupies the northern part of Bohai Bay. Well Nanpu-54 at the field was completed at 5,500 m TVD, where the bottom-hole temperature reached $195^{\circ} \mathrm{C}$ (Zhu et al. 2009). The drilling program is given in Table 6. Drilling through layers of unconsolidated sands and brittle shales presented challenges for drilling mud. The drilling mud must generate low filtrate loss and high competence in shale stability. As such, the mud was formulated with sea water, formate salt, and glycol to achieve the desired performance. The detailed mud formula is presented in Table 7.

Mud samples were aged at $200{ }^{\circ} \mathrm{C}$ for $16 \mathrm{~h}$ in laboratory, and the mud properties are presented in Table 8 . After aging, the mud still demonstrated good performance, especially the very low filtrate loss. During drilling, mud samples were taken at various depths and the properties were measured and are presented in Table 9. While drilling progressed deeper, mud plastic viscosity and yield point declined, but remained at an acceptable level, while the mud filtrate loss remained low. The drilling, logging, and cementing operations were successful without accidents. Caliper log showed the wellbore was only $1.8-4.5 \%$ larger than bit size, indicating excellent wellbore integrity.

\section{Jilin field, China}

Four wells at Jilin field in northern China were drilled with solid-free glycol mud ( $\mathrm{Li}$ and $\mathrm{Li} 2012$ ). The sandstone field was characterized with low porosity (4\%), low permeability $(50 \mathrm{md})$, and high bottom-hole temperature $\left(160^{\circ} \mathrm{C}\right)$. Therefore, a solid-free mud was designed to drill through the 
Table 7 Mud formula for Nanpu-54

\begin{tabular}{lll}
\hline Material & Concentration & Function \\
\hline Clay & $5 \%$ & To provide initial viscosity \\
Potassium formate & $5 \%$ & To inhibit shale swelling \\
Glycol & $2 \%$ & To inhibit shale swelling and reduce filtrate loss \\
SMP & $2 \%$ & To reduce filtrate loss \\
SPNH & $2 \%$ & To inhibit shale swelling and provide lubrication \\
DSP & $2 \%$ & To reduce filtrate loss \\
A-20 & $0.1 \%$ & To maintain mud performance at high temperature \\
SP-80 & $0.3 \%$ & To maintain mud performance at high temperature
\end{tabular}

Table 8 Mud properties after aging

\begin{tabular}{llllll}
\hline Mud sample & Density $(\mathrm{g} / \mathrm{ml})$ & $\begin{array}{l}\text { PV } \\
(\mathrm{cp})\end{array}$ & $\begin{array}{l}\text { YP } \\
(\mathrm{Pa})\end{array}$ & $\begin{array}{l}\text { Gel at } \\
10 \text { min } \\
(\mathrm{Pa})\end{array}$ & $\begin{array}{l}\text { Filtrate } \\
\text { loss } \\
(\mathrm{ml})\end{array}$ \\
\hline Before aging & 1.5 & 80 & 24 & 8 & 3 \\
After aging & 1.5 & 45 & 12 & 20 & 4 \\
\hline
\end{tabular}

Table 9 Mud properties at various depths

\begin{tabular}{lllll}
\hline Well depth $(\mathrm{m})$ & PV (cp) & YP (Pa) & $\begin{array}{l}\text { Gel } \\
\text { strength } \\
(\mathrm{Pa})\end{array}$ & $\begin{array}{l}\text { Filtrate } \\
\text { loss }(\mathrm{ml})\end{array}$ \\
\hline 4600 & 40 & 20 & 12 & 5 \\
4800 & 40 & 17 & 18 & 4 \\
4900 & 45 & 16 & 11 & 4 \\
5000 & 33 & 10 & 5 & 6 \\
5200 & 26 & 9 & 5 & 6 \\
\hline
\end{tabular}

Table 10 Mud properties at various temperatures

\begin{tabular}{llll}
\hline $\begin{array}{l}\text { Test temperature } \\
\left({ }^{\circ} \mathrm{C}\right)\end{array}$ & PV $(\mathrm{cp})$ & $\begin{array}{l}\text { Filtrate Loss } \\
(\mathrm{ml})\end{array}$ & Gel 10 s (Pa) \\
\hline 25 & 25 & 6.0 & 0.5 \\
120 & 30 & 5.6 & 1.5 \\
140 & 31 & 5.8 & 1.5 \\
160 & 32 & 5.9 & 2.0 \\
\hline
\end{tabular}

pay zone to reduce formation damage. The mud was formulated with water, $3 \%$ glycol, sodium formate, biopolymer as thickener, and PAM as filtrate depressant. The mud was first tested in laboratory, and the results are given in Table 10. It can be seen the mud system maintained good viscosity and low filtrate loss at high temperature. The mud also demonstrated good performance under contamination of calcium ions, as shown in Table 11.

The wells were drilled to $4,100 \mathrm{~m}$. While drilling the wells, mud properties were carefully controlled with mud
Table 11 Mud properties under effects of aging and calcium ions

\begin{tabular}{|c|c|c|c|c|}
\hline Test sample & Test condition & PV (cp) & $\begin{array}{l}\text { Filtrate } \\
\text { loss } \\
(\mathrm{ml})\end{array}$ & $\begin{array}{l}\text { Gel at } \\
10 \mathrm{~s}(\mathrm{~Pa})\end{array}$ \\
\hline Base mud & $25^{\circ} \mathrm{C} /$ no aging & 23 & 6.0 & 1 \\
\hline Base mud & $160^{\circ} \mathrm{C} / 24 \mathrm{~h}$ aging & 28 & 6.0 & 2 \\
\hline $\begin{array}{l}\text { Base } \\
\text { mud }+2 \% \mathrm{CaCl} 2\end{array}$ & $25^{\circ} \mathrm{C} /$ no aging & 23 & 6.5 & 1 \\
\hline $\begin{array}{l}\text { Base } \\
\text { mud }+2 \% \mathrm{CaCl} 2\end{array}$ & $160^{\circ} \mathrm{C} / 24 \mathrm{~h}$ aging & 30 & 6.0 & 2.5 \\
\hline
\end{tabular}

additives. The mud properties at various depths are presented in Table 12. Moreover, the mud density was controlled at $1.05-1.15 \mathrm{~g} / \mathrm{ml}$ to achieve underbalanced drilling condition. The solid-free mud system required solid control equipment working at high efficiency. On the other hand, corrosion inhibitors were applied to reduce corrosion from sodium formate. Compared with nearby wells drilled with clay mud, glycol mud achieved high ROP and high gas production rates after wells came on stream, as shown in Table 13.

\section{Huaz field, China}

The Huaz field is located in Jiangsu basin in southeast China. The field features thin pay zones with low permeability. At early stage of field development, KCl-polymer mud was used in drilling, but 3 wells experienced severe lost circulation, and 6 wells encountered wellbore sloughing, which resulted in stuck pipe, formation damage, and more than $100 \mathrm{~h}$ of non-productive (He et al. 2009).

In 2007, glycol mud was used in drilling 21 wells at the field. The mud was made of 5\% clay, $3 \%$ glycol, and other chemicals. While drilling, mud funnel viscosity was controlled at $45-50 \mathrm{~s}$, mud PV was $18-20 \mathrm{cP}$, and fluid loss was below $5 \mathrm{ml}$. The mud solid content was controlled below $10 \%$ with solid control equipment. With glycol mud, average drilling time reduced by 10 days, wellbore washout was less than $6 \%$, and very low formation damage was observed. 
Table 12 Mud properties at various depths during drilling of well No. 6

\begin{tabular}{lllllll}
\hline $\begin{array}{l}\text { Depth } \\
(\mathrm{m})\end{array}$ & $\begin{array}{l}\text { Density } \\
(\mathrm{g} / \mathrm{ml})\end{array}$ & $\begin{array}{l}\text { PV } \\
(\mathrm{cp})\end{array}$ & $\begin{array}{l}\text { YP } \\
(\mathrm{Pa})\end{array}$ & $\begin{array}{l}\text { Gel at } 10 \mathrm{~s} \\
(\mathrm{~Pa})\end{array}$ & $\begin{array}{l}\text { Funnel viscos- } \\
\text { ity } \\
(\mathrm{s})\end{array}$ & $\begin{array}{l}\text { Filtrate Loss } \\
(\mathrm{ml})\end{array}$ \\
\hline 3100 & 1.05 & 22 & 8 & 0.5 & 75 & 7 \\
3500 & 1.10 & 29 & 11 & 1.5 & 86 & 5 \\
3800 & 1.11 & 31 & 12 & 1.5 & 82 & 4 \\
4200 & 1.11 & 32 & 13 & 2.0 & 85 & 4 \\
\hline
\end{tabular}

Table 13 Comparison of clay mud and glycol mud

\begin{tabular}{lllll}
\hline Well no. & Mud type & $\begin{array}{l}\text { Solid fraction } \\
(\%)\end{array}$ & $\begin{array}{l}\text { ROP } \\
(\mathrm{m} / \mathrm{hour})\end{array}$ & $\begin{array}{l}\text { Gas } \\
\text { production } \\
\text { rate } \\
(1000 \mathrm{~m} 3 / \\
\text { day) }\end{array}$ \\
\hline 101 & Emulsion mud & 17 to 31 & 1.65 & 110 \\
301 & Polymer mud & 15 to 26 & 1.26 & 89 \\
006 & Glycol mud & 0 & 1.95 & 150 \\
304 & Glycol mud & 0 & 2.01 & 120 \\
204 & Glycol mud & 0 & 2.03 & 130 \\
\hline
\end{tabular}

\section{Changning Field, China}

The Changning and Weiyuan shale gas fields are located in south Sichuan basin, west to the city of Chongqing with 10 $\mathrm{Bcm}$ gas reserve (Xie 2018). The primary producing zone is the Longmaxi (LMX) formation about 300-400 $\mathrm{m}$ in thickness. XRD analysis showed the mineralogy was mainly clay, quartz, and dolomite. Drilling started in 2009, and 127 wells were producing a total of 8.14 million $\mathrm{m}^{3} /$ day of gas from the two shale plays in late 2018.

Even though OBM has dominated the shale drilling market, innovations in WBM lead to a few successful field applications at major shale plays (Deville et al. 2011). Well Ning206 was drilled with a mud made of 3\% clay, $4 \%$ glycol,
$10 \%$ organic salt, and other chemicals. The glycol mud was used to drill from $1680 \mathrm{~m}$ to $1920 \mathrm{~m}$. While drilling, the funnel viscosity was around $41 \mathrm{~s}$, mud PV was $12-16 \mathrm{cP}$, mud YP was 1-4 Pa, and fluid loss was less than $4 \mathrm{ml}$. Mud rheology was stable over long drilling time. Glycol mud produced very good wellbore stability with $1.2 \%$ washout and high rate of penetration (ROP). PDC bit achieved ROP of $11 \mathrm{~m} / \mathrm{h}$ with glycol mud, while ROP was $6.3 \mathrm{~m} / \mathrm{h}$ with three-cone bit (Xiao et al. 2011).

\section{Summary and discussions}

The field cases surveyed are summarized in Table 14 . According to the field cases, glycol mud demonstrated 4 advantages. (1) The primary purpose of glycol mud is to battle wellbore instability. Most field cases reported that glycol mud produced excellent wellbore integrity. When temperature exceeds CPT, glycol separates from mud, coats rock surface, and plugs the small fractures in shales. This process reduces the contact between mud and reactive shale, thus enhancing wellbore stability. (2) Several field cases reported that glycol mud maintained excellent stability under high BHT up to $200{ }^{\circ} \mathrm{C}$. This proves glycol is able to enhance the thermal stability of mud chemicals. (3) Some wells drilled with glycol mud reported excellent ROP. The high ROP is attributed to the good lubricity, low solid contents, and

Table 14 Summary of field cases with glycol mud

\begin{tabular}{|c|c|c|c|}
\hline Location & $\begin{array}{l}\text { Number } \\
\text { of wells }\end{array}$ & Challenges & Drilling results \\
\hline Bohai Bay & 1 & $\begin{array}{l}\text { High temperature }\left(200^{\circ} \mathrm{C}\right) \text {; brittle shale; high risk of } \\
\text { lost circulation }\end{array}$ & Good well stability; good lubricity \\
\hline Yuedong block in Bohai Bay & 7 & High risk of wellbore instability & Good wellbore integrity \\
\hline BZ251 block in Bohai Bay & 7 & $\begin{array}{l}\text { High risks of formation damage; high risk of lost } \\
\text { circulation; }\end{array}$ & ROP higher than OBM; low formation damage; \\
\hline Jidong field & 1 & High temperature $\left(195^{\circ} \mathrm{C}\right)$; & Excellent wellbore integrity \\
\hline Jilin field & 4 & $\begin{array}{l}\text { High temperature }\left(165^{\circ} \mathrm{C}\right) \text {; low porosity and low } \\
\text { permeability }\end{array}$ & High ROP; high production rates \\
\hline Huaz field & 21 & $\begin{array}{l}\text { Low permeability; lost circulation; wellbore instabil- } \\
\text { ity }\end{array}$ & $\begin{array}{l}\text { Good wellbore integrity; reduced drilling time; } \\
\text { low formation damage }\end{array}$ \\
\hline Changning field & 1 & Reactive clay; shale sloughing & High ROP; good wellbore integrity \\
\hline
\end{tabular}


reduced bit balling when glycol mud is used. (4) Several field cases reported low skin factors and high production rates. After glycol forms a barrier on rock surface, the flow of mud into the rock is restricted, leading to low formation damage and low skin factors.

\section{Conclusions}

Glycol demonstrates a unique cloud point phenomenon. When temperature exceeds CPT, glycol separates out from mud. Glycol then forms a coat on rock surface and plugs the small rock fractures. As a result, contact between mud and rock is reduced and wellbore stability is enhanced. In recent years, glycol mud gained popularity in Chinese fields. This paper surveys more than 40 wells drilled with glycol mud. According to field experiences, glycol mud led to excellent wellbore integrity, good thermal stability, high ROP, and low formation damage.

Open Access This article is licensed under a Creative Commons Attribution 4.0 International License, which permits use, sharing, adaptation, distribution and reproduction in any medium or format, as long as you give appropriate credit to the original author(s) and the source, provide a link to the Creative Commons licence, and indicate if changes were made. The images or other third party material in this article are included in the article's Creative Commons licence, unless indicated otherwise in a credit line to the material. If material is not included in the article's Creative Commons licence and your intended use is not permitted by statutory regulation or exceeds the permitted use, you will need to obtain permission directly from the copyright holder. To view a copy of this licence, visit http://creativecommons.org/licenses/by/4.0/.
Bol G, Wong S, Davidson C (1994) Borehole stability in shales. In: SPE drilling and completion, June 1994, pp 87-94

Deville J, Fritz B, Jarrett M (2011) Development of water based drilling fluids customized for shale reservoirs. In: SPE 140868 presented at SPE international symposium on oilfield chemistry, Woodlands, Texas. 11-13 April 2011

Gao C (2017) Petroleum drilling technology. Science Press, Beijing, pp 55-61

Gao C (2018) Petroleum production technology. Science Press, Beijing, pp 95-99

Gao C (2019) Drilling fluids for high temperature wells. Pet Coal 61(6):1479-1486

He Z, Xue Q, Ju W, Song B (2009) Application of low-damage drilling mud in low-permeability Huaz field. Drill Fluid Complet Fluid 26(1):9-11

Hu S, Bai J, Liu B, Li G (2003) Study of thermal stability of glycol drilling fluid. J Qingdao Univ Sci Technol 24(4):366-368

Li R, Li D (2012) Solid free formate mud for underbalanced drilling at Jilin field. Drill Fluid Complet Fluid 29(6):24-27

Li S, George J, Purdy C (2012) Pore pressure and wellbore stability prediction to increase drilling efficiency. J Petrol Technol 64:98-101

Liao X, Yu M, Zhang Z, Liu Y (2014) KCl-Glycol mud for drilling Yuedong block at Bohai Bay. Drill Fluid Complet Fluid 31(2):89-91

Liu Z, Guo H (2014) Application of Hib-drill mud at BZ251 field. J Oil Gas Technol 36(11):155-158

Niu G (2010) Drilling fluid for high-temperature well Boshen-8. Modern Bus Trade Ind 9:326-327

Wang L, Wu Z, Zeng J, Wang W (2009) Study of cloud point of glycol in drilling fluid. Drill Prod Technol 32(6):85-87

Xiao J, Yang L, Li M, Jia X (2011) Application of glycol mud in drilling shale gas wells. Drill Fluid Complet Fluid 28(6):21-23

Xie J (2018) Practices and achievements of Changning-Weiyuan shale gas project. Nat Gas Ind 38(2):1-7

Zhu K, Lu Q, Xu T (2009) Application of formate mud in high temperature Nanpu-54 well. Drill Fluid Complet Fluid 26(2):49-52

\section{References}

Amani M, Jubouri M, Shadravan A (2012) Comparative study of using oil-based mud versus water-based mud in HPHT field. Adv Petrol Explor Dev 4(2):18-27 